European journal of American studies

\title{
Rugged Resonances: From Music in McCarthy to McCarthian Music
}

Julius Greve and Markus Wierschem

\section{(2) OpenEdition}

\section{Journals}

Electronic version

URL: https://journals.openedition.org/ejas/12330

DOI: $10.4000 /$ ejas. 12330

ISSN: 1991-9336

Publisher

European Association for American Studies

Electronic reference

Julius Greve and Markus Wierschem, "Rugged Resonances: From Music in McCarthy to McCarthian Music", European journal of American studies [Online], 12-3 | 2017, Online since 05 December 2017. connection on 08 July 2021. URL: http://journals.openedition.org/ejas/12330 ; DOI: https://doi.org/ $10.4000 /$ ejas. 12330

This text was automatically generated on 8 July 2021.

Creative Commons License 


\title{
Rugged Resonances: From Music in McCarthy to McCarthian Music
}

\author{
Julius Greve and Markus Wierschem
}

\begin{abstract}
He sat there for a long time, watching the lights go out one by one over the valley. Sound of voices close and urgent on the acoustic night air, doors falling to, laughter... An encampment settling for rest, council fires put out... In caverns by torchlight a congress of fiends and warlocks rattling old dry bones in wistful hunger.

Cormac McCarthy, The Orchard Keeper (66)
\end{abstract}

1 There are innumerable ways in which to navigate the worlds spawned by Cormac McCarthy's narratives. Scholars, critics, and enthusiasts have interpreted the author's works from nearly every possible angle available, it seems; from philosophical to theological, from historical to political analyses, from style studies and literary periodizations to intermedial and biographical examinations. Despite this plethora of accounts-or maybe because of it-Vereen Bell's verdict from three decades ago seems as apt as ever: "Writing about McCarthy is an oddly embarrassing project because one is always saying either more or less than needs to be said, and always, in any case, in a version of the language that by comparison with McCarthy's seems poignantly inept" (Bell xiii). What, however, if the language used to approach McCarthy were not one governed by the symbolic encoding of thought in letters, words, and sentences?

In a way, Bell's verdict reflects a problem also faced by anyone challenged to write about music. It is in this twofold relation of ineptitude, and also because Bell rightfully continued that, in any event, "McCarthy needs to be written about" (a statement that is as true today as back in 1988), that we have chosen as our two worlds to be navigated the realms of literature, or prose, on the one hand, and that of sound, or music, on the other. As a number of scholars have noted, McCarthy's narratives are replete with allusions and direct references to the aural or sonic realms; vice versa, artists working in these very realms have taken note of McCarthy's work. Music and literature, sound and fiction-these two sister arts entertain a relation that is full of creative tensions and artistic intersections, resonating both within and beyond the worlds spawned by McCarthy's novels. 
3 To reduce the complexity of this resonance, we want to trace two specific links that tie the realm of the author's narrative prose to that of musical expression and, by the same token, to the world of resonance tout court-that is to say, sound and its aesthetic practices. In articulating the interaction between McCarthy and music, we will first delineate the adaptation of some of McCarthy's works to the screen with respect to the role of musical realization, that is, the scores of All the Pretty Horses and The Road. Second, we will trace the influence McCarthy's work has had in the music world by inspiring an incredibly diverse set of artists and bands including Ben Nichols, Buddie and the Huddle, Earth, and Neurosis. Progressing from these two entry-points of film scores and popular music, we hope to shed light on what, compared to the relation between McCarthy's fictions and visual culture, is an understudied area.

Yet, is there a distinct relation between his prose and the realm of sound at all? In other words, does a signature resonance exist between the world of McCarthy's fiction and that of musical practices and the discourses about them? And, if so, is it as "rugged" as the land- and mindscapes of the Appalachian and Southwestern environs and characters the reader encounters in novels like Child of God (1973) or The Crossing (1994)? Is such an aesthetic, cultural, and potentially political category applicable to the world of music in the first place? We do not propose to provide a definitive answer here, but rather to trace McCarthy's sonic signature through a number of musical examples, with varying (cultural, stylistic, philosophical, and affective) points of reference. While there are, in fact, McCarthy scholars who have already examined parts of these issues, ${ }^{1}$ it remains to be said what this signature resonance comprises and generates, oscillating between the fictive and the audible, or-to use the more McCarthian vernacular-between the word and "the warp of the world" (The Crossing 405). To recall Bell's verdict concerning criticism's hopeless inaptitude in coming to terms with McCarthy, then, the traditionally most imperceptible or elusive of the artsmusic-seems to offer a privileged (because structurally isomorphic) insight into the work of a writer whose tales continue to perplex his readers by seemingly withdrawing from each and every scholarly gesture to begin with.

\section{Music in McCarthy: Between the Page and the Silver Screen}

5 What do we mean by McCarthy's signature resonance? A certain, unmistakably McCarthian quality, to be sure-something of a dying man's childhood hymns, that, sung "with great clarity and intention," impels even Blood Meridian's (1985) vicious scalp hunters to ride "more slowly the longer to hear him for they were of just these qualities themselves" (119). Yet, is the nature of this quality (inter-)textual, sociocultural, historical, emotive, philosophical? In any case, it is not exactly a stand-in for any stylistic "essence" of McCarthy's craft, but rather the imaginary template for literature's sister arts, like film or music, to latch on to. Put differently, we will not offer any conclusive designation of this concept, but rather an outline of its effects within the world of music, in the form of influence, inspiration, and homage. In literary terms, and as evidenced by this essay's epigraph, taken from The Orchard Keeper (1965), McCarthy regularly works with references to sound in order to describe a certain mood -in this case, the haunted (anti-/eco-)pastoral sentiment so central to the novel. No matter, if the narrator is depicting Appalachian "voices close and urgent on the 
acoustic night air, doors falling to, laughter," or the ways in which "[j]ays were in the blackoaks mornings and the grackles had come back, great flocks of them bending the trees, their feathers glinting dark metal colors and their calls harshly musical, like a rusty swing" (The Orchard Keeper, 66, 65), McCarthy's poetics are finely attuned to the sonic lay of the land his narratives are set in.

In other words, The Orchard Keeper sets up a certain stylistic idiosyncrasy-or signature resonance-that develops throughout McCarthy's fiction. Other examples include the sonically informed renderings of the grim triune's killing spree in Outer Dark (1968), "advancing against the twilight, the droning bees and windtilted clover" (35); the sensual description of friendship and the onset of love between Wanda and the protagonist in the second half of Suttree, with "her body soft and naked under the dress touching him, the mussels dripping and swinging from the lines and clacking like castanets" (Suttree 351); the "flutes made from human bones" (Blood Meridian 52) in McCarthy's first Western; and the account of a mythical dream recalled in the epilogue of Cities of the Plain (1998), in which we read about a "drummer with his drum of saltcured rawhide stretched upon a frame of ash and this he beat with a sort of flail made of a hardwood ball tethered to a stick. The drum gave off a low note of great resonance and he struck it with an upward swing of the flail and at each beat he bent his head to listen as perhaps a man who were tuning a drum" (275).

7 In his seminal study The Soundscape: Our Sonic Environment and the Tuning of the World (1977), R. Murray Schafer writes, "keynote sounds are those which are heard by a particular society continuously or frequently enough to form a background against which other sounds are perceived." He goes on to state that these "sounds are not consciously perceived, but they act as conditioning agents in the perception of other sound signals" (272). In starting our analyses of film music and popular music inspired by McCarthy's fictional worlds, we posit that the investigation of the writer's signature resonance is a helpful road to take, conceptually speaking, first, in terms of Schafer's "keynote sounds" understood as "conditioning agents," and, second, in more metaphorical terms: along the lines of Bell's quest for an adequate language to address McCarthy's works, it is perhaps best to take one's cue from McCarthy himself and conceive of each and every artist and group discussed in this essay as embodiments of precisely that drummer from Cities of the Plain, bending "his head to listen as perhaps a man who were tuning a drum" (275); the "drum" with its rugged "saltcured rawhide" in our context standing for McCarthy's oeuvre itself. In this passage from the final pages of the Border Trilogy and comparable instances in McCarthy's fiction, his work premeditates its sonic interpretations and adaptations insofar as its poetics functions in terms of an imagery of sound in the first place.

8 Listening for the sonic repercussions and intermedial echoes of the rhythmic clacketyclack, bing, and zip of McCarthy's Olivetti, our point of departure, then, is the music that was written to complement the filmic adaptation of his work. From Richard Pearce's early The Gardener's Son (1977), through Billy Bob Thornton's ill-fated All the Pretty Horses (2000), to the Coen Brother's award-winning No Country for Old Men (2007), John Hillcoat's The Road (2009), Tommy Lee Jones's production of The Sunset Limited (2011), James Franco's independent version of Child of God to Ridley Scott's The Counselor (both 2013)-moving pictures made of McCarthy's work have become a common sight. It is only in three cases though, that these pictures have gone with a fully realized, commercially available musical score as well. Of these three, the scores to All the Pretty 
Horses and The Road provide pertinent examples-notable for their genesis as well as their contrasting compositional philosophies-of the different routes musicians take in transforming or, where this should prove impossible, adapting McCarthy's signature in the context of both film and music. ${ }^{2}$

Film scores written to suit McCarthy-on-screen are eminent examples of sonic ripples inspired by his work. Even so, they present a special case, given that they are forged to fit into the larger, collaborative effort that is the audiovisual medium of the motion picture. As such, they are a part of the relation the picture establishes to McCarthy's writings, and which according to Stacey Peebles (drawing on Thomas Leitch) may adopt a more curatorial or a superimpositional approach (2017). ${ }^{3}$ In this sense, scores are typically interpretations of the second order, written to fit the larger adaptation that is the film rather than the novels. While we do not know to what degree McCarthy's novel influenced Daniel Lanois' eventually rejected original score to All the Pretty Horses, the latter is exceptional in being created in direct exchange with the making of the film. In fact, it directly informed the work on set. In contrast, the replacement score by Stuart, Wilkinson, and Paxton is nothing if not curatorial, yet the object curated is hardly McCarthy's novel, but rather a musical catalogue of romanticized folk and Western clichés. Finally, Nick Cave and Warren Ellis's score to The Road is hardly lacking in vision, standing as an autonomous work of merit, yet may also be found not to gel with either McCarthy's novel nor Hillcoat's adaptation thereof.

The story of the unmaking of Billy Bob Thornton's All the Pretty Horses has been widely documented, creating, to some biblio- and cinephiles, the myth of a lost cinematic masterpiece on par with Sergio Leone's original cut of Once Upon a Time in America (1984) or what Alejandro Jodorowsky tried to create with Dune in the early $1970 .{ }^{4}$ In this respect, the loss of Thornton's vision cannot be separated from the loss of All the Pretty Horses's original score: While shooting the movie, Thornton adopted a technique also employed by Leone, who often played parts of Ennio Morricone's scores on the set of his westerns. ${ }^{5}$ Thornton, too, purposely used the original music of composer Daniel Lanois to set the mood of a scene, and to put his actors into a mindscape suited to channel what they saw as the emotional core of the novel. Matt Damon, who starred as John Grady Cole, emphasizes both the historical significance and the affective centrality of this approach:

As you know, the Cormac McCarthy book is set in 1949 and is about a guy trying to hold on to his old way of life. The electric guitar became popular in 1949, and the composer Daniel Lanois got an old 1949 guitar and wrote this spare, haunting score. We did the movie listening to his score. It informed everything we did.

11 Similarly, Peter Josyph quotes Thornton as explicitly anchoring the film's raison d'être to the quality of the score, saying: “This is what the film is about"' (192). Listening for McCarthian resonances, one must thus ask what exact qualities "this" entails. Certainly, there is the historical-musical context brought up by Damon, yet executive producer Joe Gordon stresses a more introspective quality of the score when he states that "[i]t put you squarely in the heads of the characters" (Harber 28). Indeed, music psychologists emphasize the central affective role of music in film:

Music proves decisive as a factor in directing mood alterations, when a matching visual stimulus allows for cognitive attribution... so long as no other-directed cognitions interfere. Many studies demonstrate that the musical expressions within a movie can influence the overall emotional impact of the latter.... Music is especially successful in doing so, when the film is relatively static, low on action, 
and neutral. In this case, music has an emotionally polarizing effect. Conversely, a discrepancy between musical and filmic expression proves to be an effective means of creating suspense. (Bullerjahn 210-11; our translation) than the words of those who heard it. ${ }^{6}$ In many of these statements, McCarthy's work is put front and center. Actor Henry Thomas describes the original cut as "a $4.5 \mathrm{hr}$ art movie with a single guitar cutting through the background as soundtrack," while drummer Victor Indrizzo stresses the score's "ethereal" and "dreamlike" effect, which indeed shines through on those tracks released on Lanois's 2005 album Belladonna (qtd. in Harber 26, 20). Editor Joan Sobel recalls "a combination of the score, scope, beauty and pacing... truer to the feel of the book" than the cinematic release, and executive producer Jon Gordon remembers a hypnotic, meditative, and lyrical experience that felt "epic and yet intimate," with the story "about as close to capturing what McCarthy did in the book as I could imagine," and the score akin to "what McCarthy might have been listening to himself when he wrote the book" (Harber 26-28). ${ }^{7}$ And these two contrasting adjectives-"epic" and "intimate"-could very well be apt descriptions of John Grady Cole's trajectory from his horse-breaking days at Don Héctor's ranch in the first volume of the Border Trilogy all the way to his romantic plans to settle down with Magdalena in Cities of the Plain. into the theaters. Miramax studios enforced the cutting down of the film from about three hours (give or take 15 minutes) to its theatrical length of 116 minutes, focusing on the romance between John Grady and Alejandra. Other than the running time, the major bone of contention was indeed Lanois's score itself, to which Harvey Weinstein personally objected. "We made this very dark, spare movie, but the studio wanted an epic with big emotions and violins" (Damon). The replacement score by Marty Stuart, Kristin Wilkinson and Larry Paxton has been described as "conventional-sounding," and burdened with "pretty cheesy string / orchestral parts;" it certainly fits the mold of a "more traditional Hollywood score" (see Harber 20). Conversely, Wilkinson stresses the importance of regional and historical genre considerations in the compositional process:

We know American folk idioms. We are really familiar with the popular music that is associated with the American West. We also know the history of the classical pieces that have become touchstones to the collective musical narrative of the American West. We wanted to combine all of those elements and bring a 'roots' and 'folk' authenticity to the writing[.] (qtd. in Harber 21)

In this respect, the score can hardly be faulted, nor can the production or musicianship on the 23 tracks, most of which clock in at under two minutes. The main theme, which functions as a leitmotif that is taken up and varied throughout (e.g. in "John Grady's Angel" and "Long Journey Home") opens with strings and castanet percussion, then swells with horns and flutes evoking a sense of adventure and wide, open ranges, rivers, and mountains. These are then juxtaposed with trumpets and Flamenco picking on the acoustic guitar that transport the listener into what surely must be a Mexican village, mid-twentieth century, complete with a Mariachi band. Along similar lines, "Cowboy's Dream" begins with prototypical Western guitar and delicate fingerpicking that is eventually accompanied by orchestral strings and woodwinds to epic flourishes, all set to a rhythm that feels like what someone with no actual experience of riding horses would think riding horses must feel like. Also, it gives musical shape to John 
Grady's dreams of the Mexican-American borderlands before he goes there. Similarly, in "Far Away," Stuart channels James Taylor to the kind of sad and lonesome cowboy song that are a dime a dozen. If there is any connection to McCarthy's signature resonance, it is with those types of imagery and ideology his narratives famously shatter, but which inform some passages in the Border Trilogy. In other words, they are the musical analog of the programmatic "oilpainting of horses" in the beginning of All the Pretty Horses:

There were half a dozen of them [horses] breaking through a pole corral and their manes were long and blowing and their eyes wild. They'd been copied out of a book... no such horse ever was that he had seen and he'd once asked his grandfather what kind of horses they were and his grandfather looked up from his plate at the painting as if he'd never seen it before and he said those are picturebook horses and went on eating. (15-16)

A score that filters tango, blues, and Mexican and American folk through a Hollywood lens, the result is frequently sweeping, adventurous, highly romantic-and sounds as though Ennio Morricone's, Dimitri Tiomkin's and Elmer Bernstein's collected western scores had been put through a blender and steeped in a barrel of thick, sweet American syrup. For all its catering to regional traditions and genre conventions, the film music, much like the cinematic cut, certainly lacks the way McCarthy's poetics suggests both an immersion in the Southeastern and -western cultures of the U.S. and a detachment from them. Consequently, whatever it may consist of, apparently his signature resonance does not rest primarily in the generic markers widely associated with southern or western country music. Indeed, if a major point of the story McCarthy spins in All the Pretty Horses is John Grady's fruitless search for a place and a way of life that does not exist anymore, it is about the many impossibilities of nostalgia, of the longing for a time or place that is not simply lost, but may never have existed anywhere but in the longing imagination to begin with. While Lanois's score may have had a "haunting sadness, a quality of something remembered rather than current" (qtd. in Harber 19), Stuart, Wilkinson and Paxton summon those all-too familiar clichés of "the Wild West" that are altogether fantasmatic, and strangely "out of tune" with McCarthy's work.

16 Exchanging sweeping vistas and Mexican villages for a post-apocalyptic wasteland, Nick Cave and Warren Ellis' music for John Hillcoat's adaptation of The Road is an altogether different score that exemplifies a different approach to the interplay of image and music. Hillcoat had already worked with Cave and Ellis on a Bad Seeds music video. In turn, the duo composed a haunting, experimental score that mixed Neil Young inspired guitar work with indigenous and traditional influences for Hillcoat's "Austern" The Proposition (2005). Cave also penned the screenplay for the film, which reverberated with a stripped-down and streamlined McCarthian poetry in its journey narrative, cast of outlaw characters, graphic violence, and the metaphysically charged, sublime landscapes of the Australian outback. As Warren Ellis had likewise "read most of his books, Blood Meridian being my favourite," (W. Ellis) as well as the script of The Road, an affinity for McCarthy was thus a given.

In contrast to Thornton and Lanois, Cave and Ellis created their score in the more traditional manner of composing music to already filmed material from Hillcoat's movie, though this musical approximation to the image was "very loose" and "often improvised... to be rather flexible and move with the changes made to the film" (W. Ellis). At the same time, the duo's philosophy of composition was also markedly 
different from the "incidental" and "generic" music of most traditional scores, the goal being to write "fully realized pieces" making "their own statement" rather than musical piecemeal: the scores "have to stand up on their own. They're not just incidental music from a film" (W. Ellis).

In this regard, the composers certainly succeed, creating a minimalist "juxtaposition of beauty and ugliness" (Allen) that frequently complements the film effectively:

The cinematography is simple and so too is the soundtrack. A malnourished Viggo Mortensen and his frightened son are set against a desolate, rugged and unforgiving terrain, and the soundtrack cleverly compliments [sic!] it with minimal instrumentation, spaced piano notes, faint, mournful violin and the occasional discordant accordion. (Allen)

There are several tracks which set to music those episodes in the novel and film where mortal danger is at its most severe, creating a sense of unease and nerve-racking suspense. "The Cannibals" introduces the group of marauders with the diesel truck, and is taken up again a second time in a scene where a woman and her child are chased, circled, and murdered by another group. The score serves as effective characterization, announcing the arrival of these groups with arrhythmic, vaguely tribal drumming, signifying both disorder and something more primordial, as well as a discord of buzzing violins and dissonant pipes that may conjure "the image of flies dancing on rotting flesh" (Allen). Similarly, "The House" evokes a subtle sense of creeping danger, setting the cello against the higher, sustained notes of violins as the pair of father and son descend into the cellar which serves as a larder for live humans. After briefly settling down as the pair hides from the returning cannibals, the silence is broken as a heavily distorted guitar shreds into the soundscape with frantic percussion and screeching violin, evoking a palpable sense of horror and breathless panic as the pair use a distraction to escape the house and run for their lives.

It is in tense moments such as these that the score best complements the action on screen. Other tracks strike a rather tender note. "The Mother" evokes a deeply elegiac, mournful mood between cello and bass, as the lead violin hovers over all but is increasingly on the verge of being overwhelmed by the darker sounds, eventually to fade, much like the mother herself. "The Road" is led by a continuous 3/4 piano progression to which a wailing violin, cello and additional strings are consecutively added, evoking a sense of intense longing. The piano line, which is taken up as a leitmotif at various points in the film has reminded more than one listener of Beethoven's "Moonlight Sonata." As such, it may be interpreted as a reflection of the absence of the wife, since the sonata form is seen as governed by the juxtaposition of a "masculine" and a "feminine" theme. While "Moonlight Sonata" was no explicit point of reference, and Ellis finds "The Road" comparatively lacking in "tension and resolve," he concedes that "there is something there... the film is soaked in the mother's absence and [it] resonates throughout" (W. Ellis). Cave concurs:

The movie is about the loss of things, the absence of things, the lack of things.... The lack of the wife/mother is present in every frame of the film. The delicate edifice of the film holds the ache of her absence, tenderly and by the tips of the fingers. The music was composed as a direct response to the film. A light, haunting, simple score with a sense of absence and loss at its heart. (qtd. in Goodman)

Still, one wonders whether the tenderness of the piece is not slightly off with regard to the novel: McCarthy's narrator emphasizes the hard rationality of the woman's suicide, leaving the "coldness" of her "final gift" and the spectral absence présente of the man's 
"pale bride" in his dreams and memories (Road 49,15). The film arguably paints a more sympathetic picture of the wife's quiet despair and contrasts the man's memories of her in overexposed, colorful, blurred images. Thus, score and film articulate loss in decisively mournful modalities, whereas the novel's narrative puts a subtle emphasis on the traumatic inability of mourning a loss too great for the man.

As with the film itself, the reception of the score was mixed. Jeremy Allen argued that "many soundtracks fall down," as "they either work as fragmented incidental accompaniments or they stand as great pieces of music that are irreconcilable with the action, but The Road manages both." Conversely, Sukdhev Sandhu deemed it "more intrusive than impactful, offering, like the film itself, only a karaoke gravitas." Talking about the compositional process, the duo of Cave and Ellis were clearly aware of the need to "hold the music back, keep it minimal and simple, light and not overloading the scenes" (W. Ellis):

In films too the music shouldn't be scene stealing, unless you need the music to take over, or assist a piece of performance to add some emotional pull or humour.... The Road has that thing that we're always aware of where the story is so loaded, and so emotionally charged that you stick a weedy violin on top of that and people will say 'get out of here.' (W. Ellis)

Despite feeling happy with the result, Ellis concedes that "[t]here were probably issues." Admittedly, the relation between music and emotions-their genesis, processing, function, and meaning across such variables as the duration and intensity of emotional states, the degree of their physiological and mental activation, and their individual evaluation-is itself still subject of scholarly debate, awarding the listener a high level of subjectivity (cf. Kreutz 549-555). Even so, there are times when Cave and Ellis's score becomes so dominant that it superimposes a level of univocal concreteness and definition onto the more ambivalent and multifaceted plurality of emotions present in McCarthy's words, Mortensen's performance, and Hillcoat's cinematography. ${ }^{8}$ Ultimately, one may also ask how appropriate it is to set the end of civilization to a small orchestra-really, to have it be accompanied by any music at all, lest it be like the music played by the boy's flute in the novel: "A formless music for the age to come. Or perhaps the last music on earth called up from out the ashes of its ruin" (66). In this regard, the consummate minimalism of the Coen/Burwell-approach in No Country for Old Men might have been the smarter road to take. ${ }^{9}$

\section{McCarthian Music: From Buddy and the Huddle to Neurosis}

Given McCarthy's rising popularity, it is not surprising that the literary call of what Madison Smartt Bell once likened to "pronouncements on the order of what Job heard from the whirlwind" (5) has been received by a steadily increasing number of independent musical artists well beyond the border of "secondary" film score adaptations. Naturally, the extent to which these artists engage McCarthy musically varies substantially, as do the musical genres they bring to bear in interpreting McCarthy's resonance. "Musical McCarthyism" may not extend beyond the namedropping of a familiar title within a single song, but it may also offer thoughtful and concerted engagement with McCarthy's tales and themes, the musical idioms of the 
region and culture he writes about, or, to paraphrase Peter Josyph, more abstractly strive "in the form and the tone... to [s]et the soul of McCarthy" to music (Harber 29).

Perhaps the earliest, notable example of a more serious effort to capture McCarthy's resonance on record was also the first disclosed to the awareness of McCarthy scholars. In the introduction to the second edition of Sacred Violence (2002), Rick Wallach referred to the musical exploits of a German group named after Suttree and his favorite Knoxville joint: "God help us, a German folk-rock band, Buddy and the Huddle, has released a full CD-length 'rock opera' of sorts based upon Suttree, sung in country English with heavy German patois." (vii). Initially released on two separate vinyl LPs, Music for a Still Undone Motion Picture Maybe Called "Suttree" (1996) was, in fact, the debut of what would henceforth become an evolving network formed around the core duo of social workers Roland Kopp and Michael Ströll. The music was partially recorded in Knoxville, which the two visited for research after having read the novel. Kopp recalls:

I said, 'Let's go to Knoxville and prove whether we can really do this.'.... We spent a lot of money but I talked to my wife and said, 'I have to do this. If I don't I will be angry some day.' It was a mission. I ordered city maps from the Knoxville tourist bureau, and in our luggage we had a tape recorder and some cameras. We flew to Memphis and then to Knoxville. Next day we rented a car and went on safari. We had the book with us and we went to all the places Suttree went. (qtd. in Johnson)

Assembling well over a dozen musicians, Kopp and Ströll took a year recording the music: "The construction of the novel is episodic, so each of us would take an episode and then we would decide on what instruments to use, and on the mood, and then we tried to get the right musicians" (qtd. in Johnson). Titles like "River," "Suttree," "Fruit Lover," "Trippin Through the Dew," "Joyce," "Ode to Leonard," "Party at the Huddle" or "Fly Them" will remind readers of places, characters, or plot points of the novel. The stylistic medley spans the variety of Americana from country, folk, boogie, and blues, to bar jazz and 60s rock, throwing in regional ingredients from New Orleans Funeral Marches to Mississippi Delta Blues for good measure, and employing the sounds of mandolin, dobro resonator, banjo, marimba, vibraphone, glockenspiel, didgeridoo and a host of brass and string instruments to various tonal colors, rhythms, and moods. The result is often learnedly atonal and even crude, as charming as it is vibrant-"an impressionistic mix of old-timey country, rockabilly and blues that fits the Fifties Knoxville, Tennessee, setting of the novel like a glove" (Johnson). And while this postTom Waitsian cornucopia of styles, sounds, and moods is admittedly "less an attempt to put the novel to music... than a compendium of the kind of tunes that could have been playing in the various low-life dives" (Johnson) that Suttree and his friends frequent, the album spans over 70 minutes and comes with extensive liner notes that demonstrate both familiarity with and affection for that most sprawling of McCarthy's novels.

Such extensive treatment is an exception, as is the selection of Suttree. Amongst most artists we found during our research, the clear favorite to receive musical treatment is Blood Meridian, which will be our focus going forth. In some cases, it is unclear whether the reference in song and album titles may not, in fact, be incidental: Independent rap duo Ill Bill and Vinnie Paz feature a song "Blood Meridian" on their album Heavy Metal Kings (2011), yet beyond the pair's quasi-McCarthian penchant for lyrics replete with obscure occult symbolism and relentless violence (cf. Juon), there is little to go by. Similarly, the British independent band Hope of the States includes a song called "Blood Meridian" on their album Left (2005), yet the latter is itself a rather typical, U2 
inspired, guitar-driven post-rock song in $4 / 4$, whose lyrics, beyond tangential references to lynchings and (urban) violence, can only with effort be construed to have anything to do with McCarthy's novel. A third example is provided by the now disbanded Canadian industrial group Numb, who entitled their final album Blood Meridian (1997). Most songs fire away at a high beats per minute ratio, featuring aggressive noise attacks over electronic melodies occasionally led by distorted vocals in the style of Nine Inch Nails, Ministry, or Marilyn Manson (cf. Aubin). Lyrically, Numb produce the kind of associative language games typical of nineties dark wave; yet of all songs, the title track belongs to a number of instrumental, industrial sound-collages composed of blubbering feedback loops and synthesizers imitating distortion guitars, with some voice samples added. In all of these cases, whatever connections to McCarthy are established are more likely the reader-listeners' than the musicians'.

The case lies differently with artists that explicitly claim a connection to McCarthy's work and Blood Meridian specifically, though again, the musical and lyrical mileage gained from such claims may vary. The Vancouver alt-country band Blood Meridian actually named itself after the novel, thanking "Cormac Mccarthy [sic] for the original inspiration" in the liner notes to Kick Up the Dust (2006). On the level of visual art, such association is even borne out: The children's drawing on the cover to We Almost Made it Home (2005) is more reminiscent of Frank Zappa's Ship Arriving Too Late to Save a Drowning Witch (1982), yet the back of the booklet shows a partly torn up polaroid of a white wall hung with a chain of white, transparent Christmas lights and a framed portrait of a black horse's head to the right. To the left is a cupboard with a stack of books atop of which one finds the familiar look of one of the old McCarthy Vintage paperbacks, most likely Child of God.

The fold-out cover of Kick Up the Dust is more evocative: A rugged frontiersman sits atop a mule, adorned with hat, musket, revolver, and gold-diggers equipment, eyes gazing watchful from his bearded face. The landscape around is a barren, rocky desert that opens to a more surreal view as one unfolds the cover: It is populated not just with snakes and what might be a southern island tribesman killing a turtle to the right, but also a goggles-and-turban-wearing dog to the left, and, more to the foreground, a black-winged angel with a sheep's head. Another sheep's head protrudes from the nether regions of a dress made of cosmic batik, and in his left he carries a curved flaming sword. The sheep-angel's right hand clutches that of a toddler in red overalls, whose death's head is crowned by a black cowboy hat. To the top half, the desert opens up to some colorful imagery, mixing a tumultuous sea (including a deep-sea diver) with iridescent cosmic nebula. The psychedelic collage thus collates the hardship and violence of the old West with occult, religious symbolism and the novel's pervasive motif of children's deaths, and juxtaposes a harsh desert landscape with the vastness of space to give a hint of cosmic insignificance.

While such artwork may be deemed suitably McCarthian, the music is arguably less so. Stylistically, Blood Meridian offer what reviewers describe alternatively as "lo-fi, countryish blues-punk" that "smacks of dust, whiskey and foul-mouthed scorn" (Raber), a "sound steeped in country, the blues and Neil Young-style Americana splattered with blood and self-deprecation a la Nick Cave" (Menze), or simply "gothic Americana, nightmare folk-rock" (Mack). Sonically, both albums are dominated by often off-tune tremolo guitar, banjo, piano, organ, tambourine, bass and drums, as well as lead vocalist and guitarist Matthew Camirand's monotonous, "twangy, flat-vowelled, 
left coast drawl" (Raber). On a thematic level, journalists took explicit (if superficial) note of the McCarthy connection-associating "dark Western themes" (Menze) and deeming the record "plenty western, a little violent, and full of hardscrabble big-sky anthems" (Ubel). In part, the connection is borne out, too, as Blood Meridian celebrate the trappings of love, desire, and jealousy, sing of suicidal minds, lethal accidents, murder and lynchings, and plunge into a contemplation of the looming existential void of meaning, held at bay only by giving oneself to a practiced, cynical low-brow hedonism, as in the title track. For all the excess and violence, one of the more successful condensations of McCarthy's resonance is the more subdued "Get Someplace Else," the lyrics of which-anachronisms aside-read as if the thoughts of Blood Meridian's characters were disclosed to anyone who might listen in the vast MexicanAmerican borderlands of the nineteenth century:

In glass we sleep and we dream / A lonely road stretched out in the dark / It's a shitty world with a shitty heart / It's why we fight. It's why we hang our heads / It's why we grow our hair. / It's why we never care. / There's a place we pray and can't be seen / In glass we sleep and we dream / of horses, goldmines, and submarines, / of mountains, and rivers, and trees.

As Sam Ubel observes, the "sense of resignation" and "contented nihilism" that infuses the songs and Camirand's "laconic lyrics," while evocative of Neil Young, are devoid of the latter's "humanist empathy." At the same time, Blood Meridian's act appears a little too self-consciously hedonist, edgy, and cool for it to come across as more than a middling rehearsal at playacting McCarthian pessimism, while dispensing with any sense of the sublime and what sympathy with the human condition may be found in his work. It is this labored edginess that is absent from the more successful attempts at coming to terms with the ruggedness of McCarthy's style.

Other musical appropriations or invocations of Blood Meridian are more definitive in where they leave the source material behind. In 2014, the North Carolina duo of vocalist/percussionist Will Howard and pianist David Lezcano released a "Blood Meridian" single under the moniker of Citizen Shade. The lyrics actually offer a fairly interesting musical miniature on the kid's conflict and the judge's allure, with Howard's smoky vocals going easy on the ear and the piano dancing delicately around the judge's verses. ${ }^{10}$ With regard to the book, however, the artistic choice of funky R\&B pop is rather puzzling: lighthearted, upbeat, driven by a jazzy piano and a brass section that recalls Peter Gabriel's "Sledgehammer," the song is a far cry from what most would expect of the book's relentless carnage and contemplation of evil.

In contrast, the Christian metal-core of Sleeping Giant's "Blood Meridian" (from Finished People, 2014) offers down-tuned guitar riffing, aggressive drumming, and vocals consisting of yells and shouts. The latter are built around dualistic antagonisms that require no interpretation: "There is a sickness / We are the cure.... / Committed to violence / Our victory sure / The whole earth can pass away / But we must endure." The bridge namedrops the title and introduces the judge: "Sweet blood meridian / Come flow and purify. / I've met the judge some say like him we never age. / Some say like him we never die." From this excerpt, one could assume that the text initially adopts the scalp hunters' perspective as "the disciples of [the judge's] new faith" (Blood Meridian 130), perhaps then to take a step back and offer a critique coming from Christian ethics. However, Sleeping Giant offer no counterbalance to the vision of a "sweet" and "purifying" blood meridian. And since the other songs on Finished People are thematically preoccupied with ideas of righteous struggle, perseverance, and 
Christian triumph, the devilish judge is for all appearances taken as a representative of Christianity, if not of Christ himself come to administer the final judgment. Despite the protean, disseminating nature McCarthy's creation has exhibited under the microscope of literary criticism, we have yet to become aware of any perspective that would allow for a reading of the judge along such lines. Until then, Sleeping Giant's interpretation must appear as diametrically opposed to the meanings articulated by the novel's ruined churches, slaughtered Christians, and Holden's anti-Christianity.

Apart from the film scores for All the Pretty Horses and The Road, tracing the above artists' connection to McCarthy, incidental or not, falls short of leading to a serious musical adaptation on or superimposition of his writings. However, there are also a number of musical efforts that reflect a deeper understanding of and artistic engagement with the source material-namely, those of Ben Nichols, Horatio Clam, Earth, and Neurosis. Nichols's EP The Last Pale Light in the West (2009) claims to be "based on the novel Blood Meridian by Cormac McCarthy" and takes its title from a phrase in the final chapter, just before the kid enters Fort Griffin's saloon. Dominated by acoustic guitar and Nichols's gravely vocal delivery, and lacking almost any percussion, the album offers a minimalist take on western and folk Americana: "Whether it's an atmospheric malaise added by an accordion on tracks like 'Davy Brown' and 'The Judge,' or the steel guitar providing an authenticity to the old-school western proclamations on the album's title track, the music is astonishingly bereft of gimmickry and feels completely genuine" (Rivera). Except for the title track, which gained some traction when it was used in an episode of The Walking Dead (S4/E6 "Live Bait") and opens the album to a tone of melancholy reflection, all of the songs constitute concise character portraits of members of the Glanton gang, reflecting a serious engagement with the narrative of the novel. The stomping "Davy Brown" makes mention of the shotgun-episode, Brown's various murders, his scapular of ears, and his death at the gallows. "Chambers" takes a more melancholic balladeer's approach in offering a narrative that goes beyond Blood Meridian, imagining a backstory for the veteran, old Grannyrat. Nichols suggests that his reason for deserting the group is his desire to rejoin a Mexican "dark-eyed love," and bemoans Chamber's murder at the hands of the Delawares, suggesting a potentially fateful course taken by his lover and her family as they resolve to "leave for California with the dawn."

Repeatedly, Nichols appropriates episodes and phrases from McCarthy's novel, to varying degrees of interpretive artistic license. Thus, the surprisingly upbeat "Tobin" has the expriest join Glanton not because, in the judge's words, the "priest would be no godserver but a god himself" (250), but rather for the more profane reason that hunting heathens "pays better than the Lord," and reflects both on the gunpowder episode and the judge's devilish nature. "Toadvine" catches the kid's longest-standing ally by the waterhole, at his moment of decision ("You wouldn't think that out here / A man could simply run clear / Out of country but oh my..."). It quotes his call for something to drink "with just a minimum risk of blindness and death" (100), and offers some of the backstory of how he lost his ears and was branded for horse thievery. ${ }^{11}$ Notably, Nichols also transposes the kid's exchange with the hermit-"God made this world, but he didnt make it to suit everybody, did he?" / "I dont believe he much had me in mind" (Blood Meridian 19) -and puts it into Toadvine's mouth: "When this world was made / Was never meant to save / Everyone in kind / And I don't believe / God much had me in mind." 
36 Finally, the kid's song itself is central as it is written from the quasi-omniscient perspective of the judge, addressing his young adversary. Through Holden, Nichols retells in condensed form the stages of the kid's initiatory journey from Tennessee and New Orleans to their first meeting in Nacogdoches, the Comanche massacre, and the kid's time with Glanton until their final encounter in Fort Griffin, yet also removes a number of ambiguities on the way: "Kid don't you know me? We are the last of the true / Drink up! Drink up! / Drink up! Drink up! / Cause tonight your soul's required of you." The accordion-driven chord progression of the chorus is taken up again by an electric guitar during the short and amorphous, drone-heavy instrumental "The Judge" and thus serves to tie the concept album together as "an uncommonly strong feat of folk storytelling" (Rivera).

Overall, if The Last Pale Light in the West fails to resonate with McCarthy's rugged signature style, it is neither on a textual level nor even musically, as Nichols' minimalist approach may not be particularly exciting, yet does not risk going sonically astray. As with the Hollywood take on All the Pretty Horses, the fault arguably lies with the pathos with which Nichols approaches the characters. Songs like "Chambers" and "Toadvine" offer deeply sympathetic and melancholic viewpoints, while "Davy Brown" and "Tobin" are so upbeat and played with such gusto that they evoke a sense that their murderous exploits are made light of-as if to suggest what a loveable bunch of scoundrels Glanton's scalp hunters were. All songs bear a distinct air of nostalgia for the rugged glory days of the frontier, glossing over the relentless violence and dispassionate outlook with which McCarthy demystifies any such sentiments.

In contrast, Detroit's musician and artist collective Horatio Clam take a less respectful, more daring and experimental approach in their self-released Blood Meridian EP (2013). Where Nichols's minimalist treatment is rooted within region-appropriate idioms, Horatio Clam is after capturing the more baroque, playful, and feverdream-like qualities of the novel. The latter are realized as a stylistically (if not compositionally) progressive mélange of rock, jazz, western, and klezmer. Throughout the album, Rhodes piano, Vox phantom guitar, organ and clarinet serve to put a dreamlike, psychedelic spin on the traditional rock band setup. Similarly, the lyrical treatment of Blood Meridian is something of an experimentalist collage: short narrative vignettes in "Epilogue," "Marionette," and "The Sun that Rises" rearrange phrasal excerpts from the novel, frequently McCarthy's painterly landscapes, to regurgitate them in the distorted voice of a male narrator, often to less than coherent effects. A similar collage technique is followed through the sung verses, realized in a flat, nasal tenor, as in "Marionette" which has its guitar and piano build to a nicely suspenseful, slowly intensifying melodic flow in $6 / 8$ before the voice sets in: "All will be known to you at last / To you as to every other man / See the savage caked in dirt / Riding out some ancient curse / A Marionette hung from the moon" (our transcript).

The atmosphere of "The Sun That Rises" is darker in tone, its introductory narration followed by a guitar attack that fades into another dreamy flow of sounds echoing Pink Floyd or the more surrealist Genesis, as well as the Beatles in its short choir passages. Once again, McCarthian landscapes are fragmentarily juxtaposed with other motifs, among them the judge's Et in Arcadia Ego. “Orion rose. Electric Kite... Eastern Eye. / The sun at dawn is the color of steel. / Cool blue sky. / May God have mercy on me. / See the child. / He speaks with words of bones and trees. / In the wild the sound of laughter" (our transcript). The song also received a multilayered music video that 
skillfully arranges Cowboy camp and Mexican and Native American art paraphernalia, while following a lonesome wanderer through a dreary Detroit cityscape. His journey is set against the simultaneous plot of a cardboard-budget community theater staging of a Sergio Leone type western play, complete with giant hats, extreme facial close-ups, and glitter-blood. In the words of guitarist David Rosman and director Hurwitz-Goodman:

We wanted to capture the atmosphere of McCarthy's book while poking fun of the melodrama and intensity of the song.... We decided a hokey, spaghetti-western play would serve that purpose.... We wanted something to go with this feeling of the Southwest, a time of violent race relations and desolate landscapes and a kind of epic, wandering loneliness. (qtd. in Abbey-Lambertz)

Seeking to be reunited with his lost Native American love-an actress in the western play-the wanderer's journey ends at his own wedding, where he and his bride are swallowed up by a giant tequila worm that is then metaleptically swallowed up by the cowboy narrator. The surrealist style, overall, is perhaps closer to Jodorowsky, whose 1970 cult western also receives a nod in an El Topo saloon sign. In sum, Horatio Clam offer a refreshingly free-spirited and humorous take on McCarthy, even as their playful, yet crude mélange is certainly more grounded in European prog- and psychedelic rock than Americana, and their haphazard approach to the text will likely strike many McCarthy purists as off key.

Ultimately, it would appear that a successful attempt at musical superimposition that stays true to McCarthy's vision might best be conjured from the ruins of genre clichés and all-too-literal adherence to his work. In a way, this is the approach taken by Dylan Carlson's band, the drone metal pioneers of Earth, on their album Hex, or Printing in the Infernal Method (2005). The title references both William Blake's The Marriage of Heaven and Hell (1790-93) and the historic hex circles that came to embellish Dutch farmer's barns and houses from the early nineteenth century onwards, a period example of which looms darkly on the cover of the album. While the origin and purpose of these hexes is somewhat obscure and subject to debate, to Carlson they suggested an occult history that would surely delight McCarthy, given Blood Meridian's tarot symbolism and the alchemical affinities of the judge: ${ }^{12}$

As someone born in America, I definitely consider myself a product of the frontier and the history of it has influenced me. This whole vast continent and these 'peoples': 'Indians,' the white man, they were all forced to deal with this place, an environment that was harsh and demanding and it forced people to react to it in a certain way. Like the 'hex' sign itself-the Mennonites are normally super Godfearing people, but when they came to America they had to invent these signs to keep evil spirits away. There's this need to protect themselves from this entity that inhabits the landscape... everything was violent and hard, everyone was violent. (qtd. in Patterson 18-19)

Turning through the pages of the booklet-which was designed by Stephen O'Malley of Sunn 0))), another self-avowed "Cormackian" (cf. Stosuy)-one finds it entirely composed of stark, black and white photographs, documents of the frontier past: ghostlike miners amidst their lorries, nameless cattle ranchers, armed men standing around a mass-grave, Indians in a group and on horseback-all staring at the viewer out of the undead past, a diffuse and scratched-up landscape composed of oil rig towers set along a river, nebulous mountains all but deforested by logging, old West town streets, locust-ridden fields, and hills of innumerable buffalo skulls, a black figure mounted atop the summit of bone. Todd DePalma's review of artwork and album is as eloquent as it is on point: 
As flippant as it seems, the truth is: it sounds exactly like this. So much of Dylan Carlson's pioneer vehicle invests in the cumulative recognition of cultural emblems and frontier snapshots in lieu of lyrics, as the cinematic turn the duo has taken becomes an eidetic narrative to these worn and stoic environs. A journey told with sewn lips and stinging ensemble of funereal country archetypes. Equipped with trombone, electric guitar, organ and lap and pedal guitars, nine tracks make their way through the dust and gray shade of memory. McCarthy writes about, song titles like "Land of Some Other Order," "An Inquest Concerning Teeth," "Raiford (The Felon Wind)" or "Tethered to the Polestar" give away the literary model behind Earth's album, which would continue to inspire titles on Earth's follow-up album The Bees Made Honey in the Lion's Skull (2008). Indeed, Carlson has repeatedly spoken admiringly of Blood Meridian, the violence and occultism of which left a deep imprint on his mind:

I was heavily influenced by the book Blood Meridian; or the Evening Redness In the West. A book that explores the real western expansion and real clash of people on this newest continent. It has been a continent that from the beginning has been alien and hostile yet possessing a bewitching beauty. 'A land of some other order. Whose geology is not of stone, but of fear.' There is an occult history to this continent, one of a continent evil in and of itself, a continent which the inhabitants have had to suffer mightily to carve their various 'New Jerusalems' out of. An infernal landscape which requires, from us, a song. (Earth PR; cf. also Patterson 19)

Yet what kind of song is it that Earth offers? While early on, Earth's music was dominated by heavy guitar distortion spread over lengthy, repetitive instrumentals that helped pioneer the drone metal genre and, sub-culturally speaking, existed in between the grunge movement and the genres of desert rock and stoner metal, Hex falls squarely into the second phase of Earth's career: Instead of distortion used exclusively, one now finds the modification of cleaner, yet dark guitar tones defined by spacious echo, tremolo, and reverb, hovering endlessly over Adrienne Davies's drum track that, much like the bone searchers of Blood Meridian's epilogue, move along at a pace that seems "restrained by a prudence or reflectiveness" which may have "no inner reality" (337).

Reviews stress the influence of country guitarists like Merle Haggard, Roy Buchanan, and Duane Eddy, and Neil Young's celebrated soundtrack to Jim Jarmusch's equally Blake-inspired arthouse western Dead Man (1995), propelled by "beautifully darkened, huge chords that resonate very slowly with every single note played with passionate conviction" (Earth PR). Another frequent association is, once again, Ennio Morricone. This may be surprising at first listen, yet imagine the sound, rhythm and feel of a track like "The Good, the Bad, and the Ugly" or "The Ecstasy of Gold" entropically drained of melody and dynamism, reduced to the drone of baritone guitar and drums, and decelerated to about $50-75 \%$ of its tempo, and what emerges might be a kind of monochromatic negative of Morricone, sounding a lot like Earth's "Blackened Americana."

Simplicity, repetition, and reduction reign, with nothing tinged in the tonal colors of nostalgia. In sequence, the songs on Hex seem much "the verification of a principle, a validation of sequence and causality, as if each round and perfect [tone] owed its existence to the one before it" (Blood Meridian 337). And in between each note, there is, too a hint of the dread at the intolerable silence of the world that the judge's violent sound and fury at once attempts to drown out and arguably relies on (cf. Dorson 114-5).

European journal of American studies, 12-3 | 2017 
If the music on Hex can therefore be deemed, in Phil Freeman's words, to be "fit to soundtrack a cinematic adaptation of Cormac McCarthy's Blood Meridian" (Carlson), this is hardly incidental, but rather the result of a highly developed "spiritual" philosophy of composition. Both Carlson and Davies emphasize a connection of their esoteric music to shamanism and ritual, striving to achieve effects akin to hierophany. As Davies says, "[m]usic can take you out of reality and transport you to another one. It's almost a meditation in a strange way.... When I play music with Earth, I experience it that way" (Carlson and Davies). However, while perhaps helpful, the genre associations above miss the mark in a way fundamental to Carlson:

When I was younger and full of hubris I believed that a 'pure' or 'original' music could be developed in a static and removed state from other music. I now realize that music, especially music containing the drone or THE NOTE, and music that effects a spiritual reaction from the listener is a continuum. It is a music that has continued throughout time and manifested itself in a number of different forms or 'genres' or 'styles.' I began to see my music as part of and a product of that continuum. I also began to see that continuum strongly expressed in historically 'American' forms. Specifically the 'genres' of 'country' and 'blues.' The truly 'cosmic American musics.' (qtd. in Earth PR)

Striving for musical hierophany, Carlson's goal is thus markedly similar to what McCarthy once disclosed to Garry Wallace as the elusive linchpin of literary aspiration, namely "truth." In the way that McCarthy once expressed that "books are made out of books" (Woodward 31), yet perhaps less troubled by this "ugly fact," Carlson stresses the view of music as a continuum: "I've always felt like the whole ownership of music is kind of a convenient fiction we have to embrace to make a living in our society, but to me music has always existed, and I view myself more as a channel for it, and it takes a certain shape 'cause it's coming through me, but if someone else is doing music, it will take a different shape." Reportedly, McCarthy once described mystical experiences as "a direct apprehension of reality unmediated by symbol," culminating with "the thought that our inability to see spiritual truth is the greater mystery" (Wallace 138). Carlson and McCarthy (and we should add William Blake) seem to approach the same question from opposite angles: how to take part in that "spiritual truth"? ${ }^{13}$ Should it be by "simply" channeling it-that is to say, sounding it-or by pondering on humanity's inability to apprehend it? In any case, the music Earth seeks is "part of something bigger... it's like you're tuning in a radio and you get this part and then you lose the signal... you're moving the radio dial and getting parts of something. For whatever reason we're not able to capture the whole thing" (Carlson). Hence, it makes little sense to talk about individual songs. If more than any direct musico-narrative engagement with Blood Meridian, the instrumental soundscapes of Hex reverberate with the McCarthian resonance we seek, it may ultimately be because that resonance is less McCarthy's, but rather the echo of a twofold pursuit of spiritual truth: once mediated through the music of McCarthy's language, once through the sonic language of Earth's music.

Finally, we turn to the group that, more than any musical act discussed so far and, arguably, tout court, has embodied McCarthy's signature resonance as a whole, both implicitly and explicitly. A pioneering underground band of extreme music, originally based in Oakland, California, Neurosis has built and established the subgenre of postmetal, which is comparable with sounds and genres like the droning guitarscapes of Earth and Sunn 0))) and the stoner rock of Sleep and Kyuss. However, starting off as a punk/hardcore act in the mid-1980s, what is important with this band is not just the 
Do-It-Yourself attitude pertaining to the founding of their own record label Neurot Records and their underground status within the metal scene until recently, nor the drug aesthetic that applies to so many bands and musicians working in these genres. Crucially, Neurosis included spiritual themes in their lyrics and ambient noise patterns in their sound, already from the 1990s onward-moves that most likely earned them the "post-" in the categorization of what kind of metal subgenre they actually belong to.

With album titles such as Souls at Zero (1992), Through Silver in Blood (1996), Times of Grace (1999), Given to the Rising (2007), or Honor Found in Decay (2012), Neurosis could have evoked the grim and rugged worlds of McCarthy's fictions by accident, but in fact, as the band's main singers, Steve von Till and Scott Kelly have professed on multiple occasions, the author who was born in Rhode Island and who grew up in Knoxville, Tennessee is actually their favorite writer. In a 2014 interview with Dave Bowes, von Till states: "I always go back to mythology, that's a good fallback. Cormac McCarthy, a favourite of both of ours, and I don't think there's any better writer in modern American English" (qtd. in Bowes). As if this statement was not already enough to confirm the literary backdrop to many of the lyrics von Till and his fellow band members in Neurosis have penned throughout more than three decades, Kelly even demonstrates a certain anticipation shared by the majority of McCarthy scholars about McCarthy's forthcoming work and a disappointment with the writer's foray into drama: "Waiting for him to write another fucking book and stop writing screenplays, though. But of course, he's gotta cash in at some point though" (qtd. in Bowes).

Regardless of whether or not Kelly's unwillingness to appreciate McCarthy's writings for the screen is justified, what is crucial is both his and von Till's enthusiasm for McCarthy's fiction-an enthusiasm which has found its way into the band's lyrics in a much more convincing way than in the case of Blood Meridian's would-be character psychologies of Blood Meridian's scalp hunters. Consider the following lines from the 2012 song "My Heart For Deliverance," off Honor Found in Decay: "Bleeding light in a life spent in broken arms, / can't return my soul to the mountain. / Desperate eyes reach the sleeping dark vessel / filling within the desert. / Visions raining destroying where I began. / Set adrift I pray to the ocean." The imagery evoked here combines the pastoral scenes rendering Arthur Ownby's aversion to the processes of modernization with the indifference of the bleak borderlands of nineteenth-century scalp hunter territory, yet the lyrics also convey a generally melancholic sentiment that permeates so many of McCarthy's novels. More striking still are the lyrics from the closing track of Given to the Rising, called "Origin," on which Scott Kelly snarls the following lines, accompanied by toned-down and clean guitars and ethereal synth-sounds, before the entire band starts to transform the song into a doom metal anthem:

All my spirits come through me when I bleed / A fractured skull in a desert well, I leave this disturbed, destroyed child will follow you / A wild and wounded beast I stand inside the sun / My heart let memories flood my mind / All the fixed, breathing strobes in the waking hours / The clouds are looming to remind me of the judgement passed on my soul / Acid stars have scarred my mind and left me as a ghost.

51 While these lyrics are certainly on a par with Blood Meridian's take on character psychology, in this case it could be argued that Neurosis alludes to Outer Dark's Culla Holme who leaves his and his sister's incestuous child in the woods, with the reference to the desert possibly signifying a moral, rather than a literal space of desertion. Apart 
from this implicit connection to McCarthy's second novel, the first line even recalls Dylan Carson's suggestion of embodying a certain resonance within a wider sonic continuum. It could, in fact, be argued that this kind of sonic, as well as spiritual embodiment or participation is a notion shared by McCarthy, on the one hand, and the musicians behind Earth and Neurosis, on the other.

Yet, apart from the lyrics, the music of Neurosis also evokes the rugged resonances of McCarthy's style: Marrying guitar-driven walls of dissonance with the beauty of quiet interludes, as in the songs "Strength of Fates" and "Enclosure in Flames," from Through Silver in Blood, might be compared with McCarthy's penchant for the semantic linkage of the dynamics of violence and the naiveté of love. This link can be witnessed, for instance, in the individual trajectories of characters like John Grady in the first and last installments of the Border Trilogy, and, in a different sense, in that of Rinthy in Outer Dark. A certain existential melancholy projected by the tunes from the band's middle period-that is, by albums like A Sun That Never Sets (2001) and The Eye of Every Storm (2004)-might also find its poetic correlative in Suttree. The protagonist of that novel lives on a houseboat near Knoxville, Tennessee, on many occasions bemoaning the deaths of family members and close friends, but always knowing that, at the end of the day, he "[floats] like the first germ of life adrift on the earth's cooling seas, formless macule of plasm trapped in a vapor drop and all creation yet to come" (Suttree 430). Indubitably, this is just one passage among many that resonate strongly with Neurosis' overall aesthetic of what could be termed a sonorous chiaroscuro between aggression and darkness, on the one hand, and a frail beauty of quietude, on the other.

\section{Rugged Resonances}

Much more could be said about Neurosis' worship of, or homage to, a distinctly McCarthian style on multiple aesthetic levels, including musical structure and dynamics, lyrical development, and image-making-both in terms of their album covers and their video art. However, in the context of our present delimitation of the highly diverse set of musical adaptations, recountings, homages, and reiterations, from the official score for All the Pretty Horses all the way to Earth's Hex and Neurosis' Honor Found in Decay, what is crucial to realize is that the most apt or creative transferences of fictional idiosyncrasy into musical categories is neither a question of imitative excellency, nor one of "fidelity" in Alain Badiou's sense-it is not important at all to be "faithful" to any source material or true to the "event" suggested by McCarthy's novelistic oeuvre. ${ }^{14}$ In other words, to successfully attune oneself to McCarthy's signature resonance has little to do with a certain musical aesthetic that the author of Outer Dark or The Crossing might share or not. Rather, to come to terms with the rugged resonances spawned by McCarthy's fictional universe is to understand and reenact a pathos-laden sound that functions outside of any straightforward glorification of preconceived and, consequently, inflationary clichés associated both with the U.S.-South and Southwestern desertscapes, although it may allude to those in a critical or even cynical manner, as does the narrator of McCarthy's first Western.

Ultimately, the question concerning the success of coming to terms with McCarthy's signature resonance is perhaps less interesting than the fact that his fictions lend themselves to such diverse and exciting interpretations and appropriations in the first place. If we recall the dream sequence from the epilogue of Cities of the Plain, describing 
a drummer whose instrument "gave off a low note of great resonance," perhaps we should appreciate each and every McCarthian instance of musical expression as a late accretion or occasion of precisely that "low note of great resonance"-sometimes realized in an exciting and intricately structured fashion, sometimes less so.

\section{BIBLIOGRAPHY}

Abbey-Lambertz, Kate. "Horatio Clam, Detroit Band, Draws on Cormac McCarthy for Haunting ‘The Sun That Rises' Video.” Huffington Post, 24 July 2013. Web. 31 Oct. 2017. https://www.huffingtonpost.com/2013/07/24/horatio-clam-sun-that-risesvideo_n_3639110.html.

Allen, Jeremy. “The Road Soundtrack.” Review. The Quietus, 21 Jan. 2010). Web. 31 Oct. 2017. http://thequietus.com/articles/03581-nick-cave-warren-ellis-the-road-soundtrack-review. Aubin, Vicki. “Numb. Blood Meridian.” Review. CMJ New Music Report No. 54510 Nov. 1997. 32. Print.

Badiou, Alain. Being and Event. Trans. Oliver Feltham. 1988. London, New York: Continuum, 2005. Print.

Bell, Madison Smartt. “A Writer's View of Cormac McCarthy.” Myth, Legend, Dust. Critical Responses to Cormac McCarthy. Manchester and New York, NY: Manchester University Press, 2000. 1-11. Print.

Blake, William. The Complete Illuminated Books. New York: Thames and Hudson, 2005. Print. Bowes, Dave, Steve Von Till, and Scott Kelly. "Neurosis: Dave Bowes Interviews Steve Von Till \& Scott Kelly Before They Devastated Temples Festival." The Sleeping Shaman. 20 May 2014. Web. 31 Oct. 2017. http://www.thesleepingshaman.com/interviews/g-q/neurosis-dave-bowesinterviews-steve-von-till-scott-kelly-before-they-devastated-temples-festival/.

Bullerjahn, Claudia. "Musik und Bild." Musikpsychologie. Das neue Handbuch. Eds. Herbert Bruh, Reinhad Kopez, Andreas C. Lehmann. Hamburg: Rowohlt, 2008. 205-222.

Carlson, Dylan (Earth). Interview by Phil Freeman. Burning Ambulance. Feb. 2011. Web. 31 Oct. 2017.

https://burningambulance.com/2011/02/25/interview-dylan-carlson-earth/.

Carlson, Dylan and Davies, Adrienne. "Talking to Earth About the Occult and Playing in a Doom Band When You're Happy." Interview by Charlie Ambler. Vice, 26 Sept. 2014. Web. 31 Oct. 2017. https://www.vice.com/en_us/article/bn5pqd/talking-to-earth-about-the-occult-and-playing-ina-doom-band-when-youre-happy-185.

Damon, Matt. Interview by Stephen Rebello. Playboy, 13 Dec. 2012. Web. 31 Oct. 2017.

http://www.playboy.com/articles/playboy-interview-matt-damon.

DePalma, Todd. "Earth. Hex; or Printing in the Infernal Method." Review. Chronicles of Chaos. 26 Oct. 2005. Web. 31 Oct. 2017. http://chroniclesofchaos.com/articles.aspx?id=2-3982. 
Dorson, James. "Demystifying the Judge: Law and Mythical Violence in Cormac McCarthy's Blood Meridian." Journal of Modern Literature 36.2 (Winter 2013): 105-121.

Earth. "Hex; or Printing in the Infernal Method." Press Release. Southern Lord. 2005. Web. 31 Oct. 2017.

https://www.southernlord.com/webroot/press/earth/.

Ellis, Jay. "'Do you see? Levels of Ellipsis in No Country for Old Men." Cormac McCarthy. All the Pretty Horses. No Country for Old Men. The Road. Ed. by Sara L. Spurgeon. London: Continuum 2011. 94-116.

---. "McCarthy Music." Myth, Legend, Dust. Critical Responses to Cormac McCarthy. Ed. Rick Wallach. Manchester: Manchester University Press, 2000. 157-170.

Ellis, Warren. "The Road and the Trials of the Soundtrack." Interview by Luke Turner. The Quietus 15 Jan. 2010. Web. 31 Oct. 2017. http://thequietus.com/articles/03551-warren-ellis-interviewnick-cave-the-road-soundtracks-and-the-trials-of-the-film-industry.

Goodman, William. "Nick Cave Discusses The Road Soundtrack." SPIN, 12 Nov. 2009). Web. 31 Oct. 2017. https://www.spin.com/2009/11/nick-cave-discusses-road-soundtrack/

Harber, Felix. "Trouble You Never Heard of. Cast \& Crew on Making Billy Bob Thornton's All the Pretty Horses." N.P.: 2015. 1-48. Web. 31 Oct. 2017. http://www.felixharber.com/home/ troubleyouneverheardof/.

Horatio Clam. "The Sun that Rises." Dir. by Jacob Hurwitz-Goodman. Online Music Video. N. p.: 2013. Web. 31 Oct. 2017. https://vimeo.com/69440779.

Johnson, Phil. "It's only words and all, but I like it." The Independent, 6 Jan. 1999. Web. 31 Oct. 2017. https://www.independent.co.uk/arts-entertainment/arts-its-only-words-n-all-but-i-likeit-1045290.html.

Josyph, Peter. "Blood Music: Reading Blood Meridian." Sacred Violence Vol. 2. Ed by Wade Hall, Rick Wallach. El Paso: Texas Western Press, 2002. 15-36.

---. Adventures in Reading Cormac McCarthy. Lanham: Scarecrow Press, 2010.

Juon, Steve. Heavy Metal Kings. Review. Rap Reviews, 26 Apr. 2011). Web. 31 Oct. 2017. http://www.rapreviews.com/archive/2011_04F_heavymetalkings.html.

Kreutz, Gunter. "Musik und Emotion.” Musikpsychologie. Das neue Handbuch. Eds. Herbert Bruh, Reinhad Kopez, Andreas C. Lehmann. Hamburg: Rowohlt, 2008. 548-572.

Lincoln, Kenneth. Cormac McCarthy. American Canticles. New York: Palgrave Macmillan, 2009.

Mack, Adrian. "Blood Meridian Sings of Jealousy, Murder, and Other Uplifting Matters." Georgia Straight, 7 Feb. 2007. Web. 31 Oct. 2017. https://www.straight.com/article-69925/blood-meridiansings-of-jealousy-murder-and-other-uplifting-matters.

Menze, Jill. Review of Kick Up the Dust by Blood Meridian. Billboard, 12 Aug. 2006: 76. Print.

McCarthy, Cormac. The Orchard Keeper. New York: Vintage, 1993. Print.

---. Outer Dark. London: Picador, 2011. Print.

---. Suttree. New York: Vintage, 1992. Print.

---. Blood Meridian, Or: The Evening Redness in the West. New York: Vintage 1992. Print.

---. All the Pretty Horses. New York: Alfred A. Knopf. 1992. Print.

---. The Crossing. New York: Vintage, 1995. Print. 
---. Cities of the Plain. New York: Alfred A. Knopf, 1998. Print.

---. The Road. New York: Alfred A. Knopf, 2006. Print.

---. The Sunset Limited. New York: Vintage, 2006. Print.

Patterson, Dayal. “A Spell in the Wilderness.” Terrorizer 137 (Nov. 2005): 18-19.

Peebles, Stacey. “On Being Between: Apocalypse, Adaptation, McCarthy." European Journal of American Studies. Special Issue of the European Journal of American Studies: Cormac McCarthy Between Worlds (Dec. 2017): 1-19.Web. 1 December 2017. http://ejas.revues.org/12283

Raber, Rebecca. Review of Kick Up the Dust by Blood Meridian. CMJ New Music Monthly 141 (2006): 32. Print.

Rivera, Daniel. The Last Pale Light in the West by Ben Nichols. Review. Slant Magazine, 13 Jan. 2009. Web. 31 Oct. 2017.

https://www.slantmagazine.com/music/review/ben-nichols-the-last-pale-light-in-the-west.

Sandhu, Sukhdev. "John Hillcoat's Adaptation of Cormac McCarthy's The Road Lacks Any

Existential Dimension.” Review. The Telegraph, 7 Jan. 2010. Web. 31 Oct. 2017.

http://www.telegraph.co.uk/culture/film/filmreviews/6946737/The-Road-review.html.

Schafer, R. Murray. The Soundscape: Our Sonic Environment and the Tuning of the World. Rochester, Vermont: Destiny Books, 1994.

Sepich, John Emil. Notes on Blood Meridian. Austin: University of Texas Press, 2011. Print.

Stosuy, Brandon. “Heavy Metal. It's Alive and Flourishing." SLATE, 19 Aug. 2005. Web. 31 Oct.

2017.

http://www.slate.com/articles/arts/music_box/2005/08/heavy_metal.html

Ubel, Sam. Review of Kick Up the Dust by Blood Meridian. Pitchfork.com, 10 Aug. 2006. Web. 31 Oct. 2017. https://pitchfork.com/reviews/albums/9292-kick-up-the-dust/.

Wallach, Rick. "Preface to the Second Edition" Sacred Violence Vol. 1. Ed by Wade Hall and Rick Wallach. El Paso: Texas Western Press, 2002. Vii-ix.

Wallace, Garry. “Meeting McCarthy.” Southern Quarterly 30.4 (1992): 134-39.

\section{Discography}

Blood Meridian. We Almost Made It Home. Teenage USA: 2004. CD.

---. Kick up the Dust. V2 Records: 2006. CD.

Britt, Dennis, Lanois, Daniel, Malo, Raul. "Porque.” All the Pretty Horses. Marty Stuart. Sony Music Entertainment/Sony Classical: 2001. CD.

Cave, Nick and Ellis, Warren. The Proposition. Mute Records: 2005. CD.

---. The Road. Mute Records/BMI: 2009.CD.

Citizen Shade. "Blood Meridian.” N. p.: 2014. MP3 file.

Hope of the States. "Blood Meridian.” Left. Sony/BMG: 2006. CD.

Horatio Clam. Blood Meridian. EP. N.P.: 2013. CD

ILL Bill and Vinnie Paz. "Blood Meridian." Heavy Metal Kings. Enemy Soil/Uncle Howie: 2011. CD. Buddy and the Huddle. Music for a Still Undone Movie Maybe Called Suttree. Glitterhouse: 1998. CD. Earth. Hex; or Printing in the Infernal Method. Los Angeles, CA: Southern Lord Recordings 2005. CD. 
---. The Bees Made Honey in the Lion's Skull. Los Angeles, CA: Southern Lord Recordings 2005. CD.

Lanois, Daniel. Belladonna. Anti: 2005. CD.

Lanois, Daniel. "Waltz for Hope." All the Pretty Horses. Sony Music Entertainment/Sony Classical: 2001. CD.

Nichols, Ben. The Last Pale Light in the West. Empty Road Music (ASCAP), 2008. CD.

Neurosis. Souls at Zero. Alternative Tentacles: 1992. CD.

---. Through Silver in Blood. Relapse Records: 1996. CD.

---. Times of Grace. Relapse Records: 1999. CD.

---. A Sun That Never Sets. Relapse Records: 2001. CD.

---. Given to the Rising. Neurot Recordings: 2007. CD.

---. The Eye of Every Storm. Neurot Recordings / Relapse Records: 2004. CD.

---. Honor Found in Decay. Neurot Recordings: 2012. CD.

---. Fires Within Fires. Neurot Recordings: 2016. CD.

Numb. "Blood Meridian.” Blood Meridian. Metropolis: 1997. CD.

Sleeping Giant. "Blood Meridian.” Finished People. Century Media: 2014. CD.

Stuart, Marty, Paxton, Larry, Wilkinson, Kristin. All the Pretty Horses. Sony Music Entertainment/ Sony Classical: 2001. CD.

The Sunset Limited. Dir. Tommy Lee Jones. HBO, 2011. DVD.

\section{NOTES}

1. See, for instance, Josyph (1995), Ellis (2000), and Lincoln (2009).

2. The third officially released score is Daniel Pemberton's orchestral, slightly jazzy music for The Counselor. This is not to say that the music of the other films does not warrant critical attention: Pearces' 1970s TV-production of The Gardener's Son featured occasional music by Charles Gross, notably during the opening and ending credits, some scene transitions and establishing shots, as well as a few moments of musical accompaniment: unobtrusive sketches of regional folk dominated by fiddle, Jew's harp, and banjo, as well as some quieter pieces featuring muted trumpets or horns and acoustic guitar. Aaron Embry's approach to scoring Child of God strikes a similar chord, employing the regional idioms of not yet commercially desublimated Appalachian country and folk, with fiddle, banjo, and bass playing to overall more upbeat effects, as in a jig or when a band strikes to play in the fair Lester Ballard visits. No Country for Old Men was widely lauded for dispensing almost completely with music for most of its running time. Finally, Marco Beltrami's score for The Sunset Limited amounted to little more than five minutes and was similarly minimal, featuring ambient recordings of urban soundscapes-police sirens, ticking clocks, newborn's wails, grown-ups shouting, and (inevitably) approaching and screeching subway trains-as well as some strings, piano and synthesizers, mixed with a choir of children's singing, some deep basses, and muezzin-like chants. 
3. In addition, there is the more fundamental issue associated with the basic relation of music and image. The latter, according to Claudia Bullerjahn, can be posed, firstly, as a question of primacy: Does the image accompany the music, as in music videos, operas or concert films, or the music the image, as is the case with audiovisual advertisements and (theoretically) most film scores (205-6). Regarding film music, a second set of questions concerns the functional relation between sound and image: How does music relate to imagery in temporal and spatial respects (structural synchronicity/asynchronicity)? On a semantic-affective level, are image and music unified (or redundant) in terms of what they respectively express? Are they complementary, so as to yield the meaning of a sequence only under consideration of both levels? Or are their effects more ambivalent, divergent, even contrary to one another, provoking a cognitive dissonance that calls for interpretation? Functionally, does the music illustrate, accentuate, reinterpret, or create a contrast to the image (narrative and associative relation; cf. Bullerjahn 209)? 4. Peter Josyph's documentary Acting McCarthy (2001) offers more than a glimpse into what the original vision of Thornton's film was supposed to be; Josyph has also written about the film's development (cf. Josyph 2010). Daniel Harber has compiled an impressive 48-page dossier of original statements from various sides of the production process (2015).

5. At the same time, this kind of approach was apparently not a one-way-street, as Victor Indrizzo recalls playing along with Lanois to a screening of parts of the picture to "try and capture the feeling of the scene" (qtd. in Harber 20).

6. On the original soundtrack, the two pieces of Lanois's compositions that remain are the diegetic, slow and delicate "Porque," which is played by a band in the film, and the "Waltz for Hope;" other re-worked cuts can be heard on Lanois's Belladonna (2005), which according to Indrizzo, "will give you a good impression of what the score was like" (20).

7. While the role of music in McCarthy's work-if or how it influences his style-is at best tangential to this essay, the comment raises the question of McCarthy's personal musical interests. One indicator might be the music referenced here and there in his works, as is exemplified by Black's love of John Coltrane in The Sunset Limited (131). On the audio commentary to Jones's adaptation, McCarthy describes himself as "an admirer of Coltrane," touches on the issue of the division between composer and musical artist at the example of Miles Davis (“'All Blues"... is just a beautiful piece of music, but I don't know whether he wrote that or not."), and gives an insight into his love of symphonic music: "Oh, I think Beethoven is the greatest composer.... People who know music tend to like Bach better, and people who are not quite so musically oriented like Mozart. I think Mozart's violin concertos are just, they're just poetry" (DVD 1:17:50-1:19:30). And as early as 1992, Richard Woodward intimated McCarthy's interest in country music.

8. Another possibility may also be that this feeling of inappropriateness is an effect of a rift between the musical force of Cave and Ellis's artistic independence on the one hand, and Hillcoat's too reverential approach to the book, which, as Stacey Peebles argues in this issue, "ultimately fails to productively superimpose Hillcoat's vision with McCarthy's" (2).

9. As hinted before, the soundtrack to No Country is minimalist and almost entirely devoid of music, with two particularly notable exceptions: One is Carter Burwell's ending credits composition "Blood Trails," which mixes percussion with minimal piano, the ebb and swell of keyboard ambience, and some deliberate acoustic guitar sketches 
to create a lingering sense of suspense and fatalistic unease in continuation of sheriff Bell's dream narrative and its sense of closure withheld. The second is Chigurh's famous coin-toss scene, the scoring of which Jay Ellis describes as an "extremely quiet but audible fade in of a few tones from a keyboard beginning when Chigurh flips the coin for the gas station man," which "grows imperceptibly in volume so that it is easily missed as an element of the mis-en-scene" to the effect of "telling our unconscious that something different is occurring with the toss; this becomes certain when it ends as Chigurh uncovers the coin... and reveals to the man that he has won" (100).

10. Switching between authorial perspective and first person introspection, the first stanza is clearly modeled after the novel's opening: "See the child / Pale and thin / Alone and he wears old linen / God how the stars did fall / In 1833 / he lies in drink, blames it on me / All history rests upon him / The child the father of the man" (our transcript). The second stanza introduces the judge and draws its inspiration primarily from the novel's ending: "See the judge / Follow me / We liked him immediately / Go down to the state penitentiary / He never sleeps / His feet are light / He dances naked all night / He said that he will never die / I believe that I'll never die." The chorus has the lyrical I-likely a version of the kid-assert: "I'm treadin' water / I keep treading water / I'm treadin' water / I can't go much further in." The background vocals, however, suggest it may be "Sinking to swim," perhaps reflecting the on the kid's need to adapt to the conditions of the Southwest and the ways of the Glanton Gang as a kind of spiritual or moral descent. The bridge then exemplifies the judge's allure and threat: "Once you heed my word, next you rule the world / Once you see the sign, next you cross the line."

11. As one observant Amazon.com reviewer of the album pointed out, the "Toadvine" reference to Omaha is an anachronism, as the latter was only founded in 1854; so is the reference to Navy Colts in "The Kid," as the latter were only introduced in 1851.

12. See Sepich $(51-55,105-117,119-127)$.

13. Significantly, the passage from which Hex takes its alternative title, "Printing in the Infernal Method," comes from a "A Memorable Fancy" in Blake's Marriage of Heaven and Hell. It is concerned, precisely, with questions of perception, specifically, of the hidden truth of the infinite, creating a direct line between Blake's prophetic poetry, McCarthy's writerly pursuit of truth, and Carlson's sonic approach to the infinite musical continuum, which mirrors McCarthy's own awareness of his place in the continuum of literature. The lyrical I's exchange with the prophets Isaiah and Ezekiel (which makes reference to a method "the North American tribes practise" to raise "other men into a perception of the infinite" [119]), is a prophetic proclamation that, apart from Dylan Carlson, also inspired the likes of Aldous Huxley: "[T] he whole creation will be consumed and appear infinite and holy whereas it now appears finite \& corrupt.... But first the notion that man has a body distinct from his soul is to be expunged; this I shall do, by printing in the infernal method, by corrosives, which in Hell are salutary and medicinal, melting apparent surfaces away, and displaying the infinite which was hid. If the doors of perception were cleansed every thing would appear to man as it is, infinite. For man has closed himself up, till he sees all things thro' narrow chinks of his cavern" (120).

14. See, for example, Badiou's Being and Event (232-9). 


\section{ABSTRACTS}

This essay explores the contact zone between the two worlds of music and literature, or sound and fiction, in the context of Cormac McCarthy's works. It teases out the stylistic idiosyncrasies of McCarthy's fiction in terms of a sonic register, by tracing its connections to the film scores of movie adaptations like All the Pretty Horses (2000) and The Road (2009), and to the works of a diverse set of musicians and bands directly inspired by McCarthy's fiction, including acts like Buddy and the Huddle, Horatio Clam, Ben Nichols, Earth, and Neurosis. Starting with specific passages from the author's oeuvre that themselves project a sonic imagery, the guiding question of this essay will be in what sense a tracing of the film scores and musical acts inspired by McCarthy's writings shed light on the "ruggedness" of what could be called his "signature resonance."

\section{INDEX}

Keywords: Music and literature, Cormac McCarthy, film scores, signature resonances, adaptation studies

\section{AUTHORS}

\section{JULIUS GREVE}

Julius Greve is a lecturer and research associate at the Institute for English and American Studies, University of Oldenburg. In 2016, he completed his doctoral studies in American literature at the University of Cologne. Greve has published articles on Cormac McCarthy, Mark Z. Danielewski, critical theory, and speculative realism, and he is the co-editor of America and the Musical Unconscious (Atropos, 2015) and Superpositions: Laruelle and the Humanities (Rowman \& Littlefield International, 2017). His book Shreds of Matter: Cormac McCarthy and the Concept of Nature will be published with Dartmouth College Press.

\section{MARKUS WIERSCHEM}

Markus Wierschem studied Philosophy, German, Media Studies, and English and American Literary and Cultural Studies at the University of Paderborn and St. Olaf College (Northfield, MN). In 2017, he received his doctorate degree for his dissertation An American Apocalypse? Myth, Violence, and Entropy in the Novels of Cormac McCarthy (MSU Press, forthcoming 2019). He is the author of numerous articles and has edited the anthology Patterns of Dis/Order: Beiträge zur Kulturgeschichte der Unordnung (LIT: 2017), as well as America(n) Matters: Selected Essays in American Studies (Winter: forthcoming 2018). He has been teaching courses on various topics of American Literature and Culture as well as the didactics of English at the University of Paderborn since 2011. 